EDUR • Educação em Revista. 2021; 37:e20852

DOI: http://dx.doi.org/10.1590/0102-469820852

() (1) https://creativecommons.org/licenses/by/4.0/

ARTIGO

\title{
DA ARTE DA CORTE À DIALÉTICA DO AMOR: A COMPLEMENTARIEDADE FORMATIVA ENTRE OS AMANTES DO SABER
}

\author{
CLAUDIO A. DALBOSCO ${ }^{1}$ \\ ORCID: https://orcid.org/0000-0003-3408-2975 \\ MARCOS SIDNEI PAGOTTO-EUZEBIO ${ }^{2}$ \\ ORCID: https://orcid.org/0000-0003-4166-9942
}

\begin{abstract}
RESUMO: O ensaio trata da ideia de Eros formativo presente no Banquete, de Platão, a partir da interpretação feita por Michel Foucault no segundo volume de sua História da sexualidade: o uso dos prazeres. Primeiro, busca-se reconstruir a arquitetônica da investigação foucaultiana acerca dos aphrodisia, que se desdobra em dietética, econômica e erótica, localizando a dialética do amor no interior da erótica. $\mathrm{Na}$ sequência, discute-se o aspecto formativo do Banquete, destacando, especialmente, a reciprocidade entre erasta (o amante) e erômeno (o amado), e assumindo que a guinada ontológica da dialética do amor aponta diretamente para a dimensão ético-formativa do Eros, de acordo com o argumento do diálogo. O Eros relacionado à beleza individual e particular (ou seja, como contingente e empírico) só pode ser superado pela perspectiva universal do amor quando for permitido a um (o erasta) assumir a posição do outro (o erômeno) e vice-versa.
\end{abstract}

Palavras-chave: Eros formativo, aphrodisia, dialética, erasta, erômeno.

\section{FROM THE ART OF COURTING TO THE DIALECTICS OF LOVE: THE FORMATIVE COMPLEMENTARITY BETWEEN KNOWLEDGE LOVERS}

\begin{abstract}
The essay deals with the idea of formative Eros present in Plato's Banquet, based on the interpretation made by Michel Foucault in the second volume of his History of Sexuality: The Use of Pleasures. First, we seek to reconstruct the architecture of Foucauldian research on aphrodisia, which unfolds into dietetics, economics, and erotics, locating the dialectics of love within erotics. In the sequel, the formative aspect of the Banquet is discussed, highlighting especially the reciprocity between erasta (the lover) and eromenon (the beloved), and assuming that the ontological turn of the dialectic of love points directly to the ethical-formative dimension of Eros, according to the argument of the dialogue. Eros related to individual and particular beauty (i.e., as contingent and empirical) can only be overcome by the universal
\end{abstract}

\footnotetext{
${ }^{1}$ Professor da Universidade de Passo Fundo (UPF), Passo Fundo, RS, Brasil. Bolsista Produtividade em Pesquisa (CNPQ). Agradeço ao CNPq pela Bolsa Produtividade em Pesquisa. E-mail: vcdalbosco@,hotmail.com.

${ }^{2}$ Professor do Departamento de Filosofia da Educação e Ciências da Educação (EDF) da Faculdade de Educação da USP (FEUSP). São Paulo, SP, Brasil. E-mail: hipias@usp.br
} 
perspective of love when the one (the erasta) is allowed to assume the position of the other (the eromenon) and vice versa.

Keywords: formative Eros, aphrodisia, dialectic, erasta, eromenon.

\section{DEL ARTE DE LA CORTE A LA DIALÉCTICA DEL AMOR: COMPLEMENTARIDAD FORMATIVA ENTRE LOS AMANTES DEL CONOCIMIENTO}

RESÚMEN: El ensayo aborda la idea del Eros formativo presente en el Banquete, de Platón, basado en la interpretación realizada por Michel Foucault en el segundo volumen de su Historia de la sexualidad: el uso de los placeres. Primero, busca reconstruir la arquitectura de la investigación hecha por Foucault acerca de los aphrodisia, que se desarrolla en dietética, económica y erótica, ubicando la dialéctica del amor dentro de la erótica. En la secuencia, se discute el aspecto formativo del Banquete platónico, destacando, especialmente, la complemetaridad formativa entre erasta (el amante) y erômeno (el amado), y suponiendo que el cambio ontológico de la dialéctica del amor apunta directamente a la dimensión éticoformativa de Eros, según el argumento del diálogo. Eros relacionado con la belleza individual y particular (es decir, contingente y empírico) solo puede ser superado por la perspectiva universal del amor cuando uno (erasta) puede asumir el la posición del otro (el eromeno) y viceversa.

Palabras clave: Eros formativo, aphrodisia, dialéctica, erasta, erômeno.

\section{INTRODUÇÃO}

O Banquete é um texto clássico que trata de um tema clássico. Platão desenvolve uma teoria inovadora do amor que desperta o interesse, ainda nos dias atuais, não só da filosofia, mas também de outros âmbitos da cultura humana, como a literatura, a teologia, a psicanálise e a educação. Partindo da compreensão corrente sobre o amor em seu tempo, eleva-o do âmbito restrito da beleza corpórea de um indivíduo particular ao da beleza universal, fazendo emergir a imbricação problemática entre as perspectivas do belo, do bom e do verdadeiro. ${ }^{3}$

Platão, no diálogo, resume o sentido teogônico, retórico, político, médico, cômico-trágico (poético) de Eros para elevá-lo, em seguida, ao nível filosófico, elaborando a dialética do amor. Nosso interesse concentra-se, neste ensaio, justamente no aspecto formativo inerente à dialética do amor. Para investigá-lo, apoiamo-nos na interpretação de Michel Foucault, desenvolvida no segundo volume da História da sexualidade, intitulado "O uso dos prazeres". Reconstruímos, na primeira parte, os traços gerais da arte da corte, evidenciando algumas limitações inerentes à moral de honra que a sustenta. Na segunda parte, trazemos à baila o núcleo constitutivo da dialética do amor, mostrando a faceta formativa tanto do erasta (amante) como do erômeno (amado). Concluímos com breves considerações sobre a atualidade da relação amoroso-formativa entre amantes, tomando-as como referência para pensar a relação pedagógica mais ampla entre educador e educando.

Procuramos sustentar o núcleo de nossa argumentação na seguinte hipótese: a guinada ontológica que garante a passagem da arte da corte à dialética do amor dependeria da força formativa de Eros. Isto é, a elevação de um ponto de vista pessoal, guiado pelo desejo humano centrado na beleza corpórea individual, para o ponto de vista abrangente, fundado na contemplação do belo em si, é possibilitada pela relação formativa complementar entre erasta e erômeno. Sendo assim, Platão lança as raízes de uma teoria educacional cujos efeitos continuam repercutindo ainda nos dias atuais, na medida em que eleva ao ponto máximo a tensão formativa entre os amantes do saber: para que ambos possam encetar o caminho amoroso pela sabedoria, precisam tomar posição ativa na relação e assumir sua própria

3 Para uma reflexão filosófica pontual sobre o problema da imbricação entre belo, bom e verdadeiro, assim como sobre outros problemas do Banquete, ver G. R. F. Ferrari (2013, p. 293-325). 
condição de sujeitos. Sendo assim, a dialética do amor exige, do ponto de vista formativo, a relação tensional e conflitiva entre seus dois polos, anelando o laço amoroso entre os amantes do saber. Nesse sentido, o Eros é justamente a força ou impulso que assegura a condição de sujeito ativo tanto ao ensinante como ao aprendente que estão a caminho em busca da sabedoria.

\section{A ARTE DA CORTE}

Foucault debruça-se sobre o Banquete no último capítulo do segundo volume da História da sexualidade, intitulado "O uso dos prazeres". Ele investiga, na referida obra, os aphrodisia como techne da arte de viver, ou seja, como amplo campo do cuidado moral, no qual os amantes (erasta e erômeno) buscam dar sentido ao que fazem ou deixam de fazer. Enquanto campo do cuidado moral, os aphrodisia contêm, primeiramente, a chresis, isto é, a "maneira pela qual um indivíduo dirige sua atividade sexual, sua maneira de se conduzir nesta ordem de coisas, o regime que ele se permite ou se impõe, as condições em que ele realiza os atos sexuais, a importância que ele lhes atribui na sua vida" (FOUCAULT, 1985, p. 51). Portanto, a chresis se refere à busca do uso temperante dos prazeres, fazendo com que paixões viciosas sejam controladas por paixões virtuosas.

No entanto, a chresis precisa da enkrateia - e esse é o segundo aspecto moral dos aphrodisia -, ou seja, da luta incessante que o sujeito deve manter consigo mesmo para fazer uso virtuoso dos prazeres. Sendo assim, a enkrateia é condição de possibilidade da sophrosyne (a temperança). Termo do vocabulário socrático que, via cinismo e estoicismo, se firmou na literatura filosófica como indicação do autodomínio, a enkrateia é caminho e garantia da vida temperante. O ponto decisivo, aqui, e que voltará, sob outra perspectiva ética, no âmbito da dialética do amor, é que, sem esforço (ponos) e trabalho sobre si (askesis), não há possibilidade de sophrosyne. A tese de que a sophrosyne depende da enkrateia precisa ser compreendida, no entanto, em sentido preciso, a saber, que o próprio modo de vida temperante só é possível como exercício e atividade contínua; ou seja, para que se possa fazer uso ético dos prazeres, é preciso uma árdua batalha diária. Porém, o que a noção de exercício significa em termos de filosofia? Mais precisamente, que noção de filosofia é capaz de assegurar o cuidado moral dos aphrodisia? Esse duplo questionamento toca em cheio o pensamento do último Foucault. Trata-se da filosofia como modo ascético de vida, ou seja, como modo reflexivo das práticas humanas, que brota de tais práticas e que procura meditar sobre elas, mas de maneira especialmente ética. É o sujeito que deve tomar a si mesmo como sujeito de ação e convencer-se de que sua vida só assumirá sentido ético quando se dispuser a tal exercício permanente, visando à sua autotransformação. Em síntese, essa noção de filosofia refere-se a uma longa e antiga tradição, segundo a qual o amor à sabedoria possui parentesco umbilical com a askesis, resultando dela e acontecendo somente por meio dela. ${ }^{4}$

No contexto dos aphrodisia, contudo, a noção de askesis assume forma bem delimitada: para que possa fazer uso adequado de seus prazeres, o sujeito deve preparar-se longa e continuamente, e os exercícios sintetizam essa forma de preparação. Tomar os aphrodisia como campo do cuidado moral significa investigar os diferentes exercícios, ou, pelo menos, aqueles mais expressivos, que possibilitam a preparação ética. Contudo, a filosofia como ascese está referida, na Grécia clássica, a um campo muito mais amplo, envolvendo todos os âmbitos de sua vida, especialmente a questão da regulação da atividade política do homem livre na polis. Essa é uma referência nuclear da relação entre Sócrates e Alcibíades, tratada por Platão em alguns de seus diálogos. A tese de fundo é sempre a mesma, a saber, que a relação entre governo de si e governo dos outros possui imbricação ética complementar, profunda e inseparável. No dizer de Foucault (1985, p. 69):

E ele [Platão] associa essa exigência do exercício à necessidade de se ocupar de si: a epimeleia heautou, a aplicação consigo que é uma condição prévia para poder se ocupar com os outros e dirigi-los, comporta não somente a necessidade de conhecer (de conhecer o que se ignora, de conhecer que se é ignorante, de conhecer o que se é), como também a necessidade de se aplicar efetivamente a si e de se exercer e se transformar.

4 Sobre a filosofia como forma de vida apoiada por exercícios espirituais permanentes, ver Pierre Hadot (2006). 
Portanto, filosofia como askesis implica a imbricação entre ética e política e, mais precisamente, a tese de que a base ética reguladora da ação política no âmbito da esfera pública (polis) pressupõe intenso processo formativo no qual a cidadania e a virtude se confundem. E, o mais importante, tal imbricação é sustentada por uma ética exigente do sujeito sobre si, cuja base repousa no autoexame, isto é, no autogoverno permanente. No dizer de Francis Wolf (1992, p. 137): "É esta relação consigo mesmo, para além das práticas e para aquém dos códigos, que é o objeto da interrogação de Foucault e a matéria de sua genealogia da moral".

No segundo volume da História da sexualidade, Foucault esquematiza os exercícios referentes ao cuidado moral que se deve ter no uso dos prazeres em três grandes dimensões, investigando em detalhes a singularidade de cada uma delas: dietética, econômica e erótica. Essas três dimensões constituem a arquitetônica dos aphrodisia e são consideradas como "práticas reconhecidas", "núcleo de problematização", "artes de se conduzir" e, principalmente, como três grandes "técnicas de si", que reúnem em seu interior o conjunto de exercícios mediante os quais o homem livre busca lapidar-se para exercer, do modo como convém, sua participação política na esfera pública. Por isso, como vimos acima, a ascese filosófica pressupõe sempre a formação humana como amálgama entre virtude e cidadania. Assim afirma Foucault (1985, p. 71):

A askesis moral faz parte da paideia do homem livre que tem um papel a desempenhar na cidade e com relação aos outros; [...] tudo isso [o conjunto de exercícios] é, ao mesmo tempo, formação do homem que será útil para a cidade e exercício moral daquele que quer se dominar a si mesmo.

Trata-se, portanto, da ampla formação que precisa dar conta, simultânea e reciprocamente, do autogoverno de si e da participação política na esfera pública (polis).

No que se refere à dietética, ela abrange o conjunto de regimes que orienta a vida do ser humano, compreendendo os cuidados do corpo que estão simultaneamente relacionados com os cuidados da alma. Nesse sentido, todo o regime físico, com seus respectivos exercícios, representa a busca de aperfeiçoamento do corpo, na tentativa de se alcançar a temperança da ação humana. Como assinala Foucault (1985, p. 97): “A dieta do corpo, para ser razoável, para ajustar-se como convém às circunstâncias e ao momento, deve ser também questão de pensamento, de reflexão e de prudência”. É por isso que, movida por esse ideal, a filosofia platônica, assim como toda a filosofia antiga em geral, deixa-se inspirar pelos Tratados hipocráticos, principalmente por sua noção ética de saúde como grande equilíbrio entre o organismo humano e a physis. A reflexão sobre o uso dos prazeres e, principalmente, como é o caso aqui, sobre os regimes, deve funcionar analogamente como na medicina, pois, visando à autonomia do paciente, o médico deve explicar e dar razões para que o próprio doente regule como convém seu modo de vida. Ora, é precisamente essa exigência ética mais ampla dos regimes (dietética) que põe a medicina antiga no caminho da filosofia, inclusive, fazendo a própria ética socrática lançar suas raízes em alguns dos Tratados hipocráticos (JAEGER, 1973)..$^{5}$

A econômica, por sua vez, é a prática do governo doméstico, referindo-se ao poder que o marido exerce sobre si mesmo na prática do poder que exerce sobre sua esposa. É como um ser casado que o homem precisa exercer como convém o domínio sobre seus prazeres. Como alerta Foucault, "ser casado significa aqui, antes de mais nada, ser chefe de família, ter uma autoridade, exercer um poder que tem na casa seu lugar de aplicação e, dentro desse quadro, manter as obrigações que têm efeitos sobre a reputação do cidadão" (FOUCAULT, 1985, p. 135).

$\mathrm{Na}$ econômica trata-se, portanto, do cultivo de si que o homem livre, enquanto marido, precisa exercer na esfera da oikos, para poder participar bem nas deliberações da polis. Refletir sobre o governo da economia familiar, sobre o que se passa dentro da casa, torna-se indispensável como preparação para a forma de governo a ser exercida na esfera pública. Nesse sentido, as escolhas sexuais e os usos dos prazeres estão também diretamente relacionados com o status de poder do homem no governo da casa e nas provas de domínio de si que ele é capaz de oferecer na prática de tal poder. Assim como na dietética, no âmbito da econômica, o princípio regulador da temperança assume a dianteira: "o homem é chamado a temperar sua conduta em função do domínio que espera exercer sobre si mesmo,

\footnotetext{
${ }^{5}$ Para uma interpretação hermenêutica gadameriana do sentido hipocrático de saúde e de sua possível atualidade, ver C. A. Dalbosco, F. Santos, R. Maraschin, e L. O. Cezar (2020).
} 
e da moderação com a qual ele quer fazer funcionar seu domínio sobre os outros" (FOUCAULT, 1985, p. 162). Desse modo, na econômica, aparece, também de maneira acentuada, o vínculo entre governo de si e governo dos outros, sendo que o bom governo dos outros depende da capacidade de domínio de si que o homem, enquanto marido, demonstra no governo da casa.

Por fim, a erótica refere-se à arte da corte que regula o comportamento amoroso entre o adulto (erasta) e o rapaz (erômeno). O cuidado moral aparece aí, nessa dimensão dos aphrodisia, como domínio que os amantes precisam exercer sobre si mesmos, evitando que haja a subjugação de um sobre o outro. Tal forma de amor denominava-se pederastia e desempenhava papel formativo importante na Grécia Clássica: ao adulto experiente cabia a iniciação do adolescente inexperiente no mundo. Como esclarece Foucault (1985, p. 174): "as relações que podem se estabelecer entre um homem mais velho que terminou a sua formação - e que se supõe desempenhar o papel social, moral e sexualmente ativo e o mais jovem, que não atingiu seu status e que tem necessidade de ajuda, de conselhos e de apoio".

É preciso considerar, também, que a reflexão filosófico-formativa sobre esse tipo específico de amor origina-se de práticas culturais complexas e que, antes de se tornarem tema de reflexão filosófica, já existiam como parte de um amplo jogo social, aberto e singular. O fato é que os comportamentos e condutas sexuais resultantes de tal jogo deveriam orientar-se pelo cuidado moral alicerçado na ética de honra do rapaz, o que, como veremos logo abaixo, não acontecia sempre e, talvez, nem na maioria das vezes.

De qualquer sorte, o núcleo dessa ética de honra assemelha-se muito ao cuidado moral próprio tanto à dietética como à econômica: "a reflexão moral então não se dedica tanto a definir com o máximo de rigor possível os códigos a serem respeitados e o quadro dos atos permitidos e proibidos, quanto a caracterizar o tipo de atitude, de relação consigo mesmo que é requerido" (FOUCAULT, 1985, p. 185).

Nesse sentido, para que possa resistir às investidas do erasta perverso ou, ao contrário, ceder livremente à sabedoria experiencial do erasta formador, o erômeno (rapaz) precisa mostrar-se, ele próprio, de algum modo temperante. Em resumo, o princípio de honra da arte da corte demarca um estilo geral de conduta: estar em constante combate consigo mesmo e exercitar-se permanentemente visando ao domínio de si, ou seja, ao autogoverno ético.

O problema é que esse tipo de amor que os aphrodisia assumem na relação entre o erasta e o erômeno nem sempre se deixa orientar pelo cuidado moral exigido. Por isso, é importante assinalar algumas limitações inerentes à arte da corte, porque são justamente elas que impulsionam a crítica platônica ao amor fugidio e, ao mesmo tempo, sua defesa do amor verdadeiro. Gostaríamos de referir, brevemente, algumas limitações relacionadas entre si. A primeira refere-se ao domínio autoritário exercido pelo erasta sobre o erômeno: enquanto detentor político e econômico do Eros, o erasta pode assumir papel ativo inquestionável, buscando satisfazer seus desejos a qualquer custo, tornando a beleza juvenil do erômeno objeto de realização de seus prazeres. A segunda limitação repousa na ameaça constante que a posição dominante do próprio erasta sofre diante da beleza juvenil do erômeno: sendo seduzido pela beleza do rapaz, o adulto dominador cai, ele próprio, na condição oposta, passando de sujeito ativo dominador para a condição passiva, de alienação irrestrita à beleza individual de seu amado. A terceira limitação refere-se à condição ambígua do erômeno no âmbito das relações amorosas corrompidas: quando passivo, torna-se objeto de seu amante, subjugando-se à força de seus desejos egoístas; no entanto, quando assume a posição ativa dominadora, subjuga, ele próprio, seu amante, tornando-o serviçal de sua beleza juvenil. Por fim, a quarta limitação diz respeito à deterioração da relação amorosa na arte da corte: por exemplo, quando o erômeno é abandonado à própria sorte pelo seu erasta; também, quando a relação assume a forma desonrosa que coloca o erômeno em dependência total de seu erasta; por último, quando o erasta impõe, no jogo amoroso, recompensas, benefícios e serviços que lançam o erômeno à vergonha, reduzindo-o à sombra na esfera pública.

Essas limitações põem em risco o ideal de autogoverno almejado pelo cuidado moral no uso dos prazeres próprios à arte da corte. De uma forma ou outra, erasta e erômeno estabelecem relações dominadoras que subjugam a um, a outro ou, simultaneamente, a ambos. Essa deterioração das relações amorosas tem efeito destruidor, porque coíbe o que é central à base ética da formação humana, a saber, que tanto amante como amado se construam como sujeitos ativos na relação. Por isso, a preocupação de PLATÃO, no Banquete, em desenvolver uma teoria do Eros que fosse capaz de garantir a passagem 
da arte da corte à dialética do amor. Na sequência, ocupamo-nos da dialética do amor e do novo perfil de erasta e erômeno que dela resulta.

\title{
DIALÉTICA DO AMOR
}

Reconstruímos, em largos traços, a arquitetônica foucaultiana do uso dos prazeres, acompanhando sua investigação tripartite dos aphrodisia como cuidado moral desdobrado em dietética, econômica e erótica. Essa reconstrução foi necessária para compreendermos melhor o modo como Foucault insere a filosofia do amor do Banquete no âmbito da erótica, concebida como arte refletida do amor. Como veremos em seguida, a arte do amor assume, no contexto específico desse diálogo, a relação com a verdade. Contudo, a arte refletida do amor caracterizada como busca da verdade só é possível pela passagem da arte da corte à dialética do amor. Nesse contexto, as seguintes questões são importantes: que forma específica o Eros [sempre maiúscula?] assume quando se refere à verdade? $\mathrm{E}$ a questão propriamente pedagógico-formativa do Banquete: que perfil e que tipo de relação assumem erasta e erômeno no âmbito da dialética do amor? Ou seja, como se apresenta Sócrates enquanto mestre da verdade e que tipo de amor Alcibíades lhe declara?

No que se refere especificamente à primeira questão, a nova significação de Eros depende, segundo Foucault, da guinada ontológica que assegura a passagem da arte da corte à dialética do amor. $\mathrm{Na}$ base dessa passagem está o deslocamento filosófico operado por PLATÃO, posicionando a reflexão sobre Eros no âmbito estritamente ontológico do problema: não se trata mais da reflexão sobre a conduta amorosa que envolve todos os ingredientes constituintes da arte da corte entre os amantes, ou seja, o que cada um deles precisa fazer de melhor para seduzir o objeto de seu desejo, mas sim da interrogação sobre o que é o amor, qual é sua natureza e como se relaciona com a verdade. Foucault assinala tal deslocamento da seguinte forma:

\begin{abstract}
Ora, colocar assim a questão implica primeiro um deslocamento do próprio objeto do discurso. Diotima reprova a Sócrates - mas de fato a todos os autores dos elogios precedentes - o ter buscado, do lado do elemento "amado" (ton eromenon), o princípio daquilo que conviria dizer do amor; eles se deixaram, portanto, ofuscar pelo charme, beleza e perfeição do rapaz amado e atribuíram esses méritos indevidamente ao próprio amor; este somente poderia dizer a sua própria verdade se a perguntasse ao que ele é e não a quem ele ama. É preciso portanto [no original citado, voltar do elemento amado àquele que ama (to eron) e interrogar nele mesmo. (FOUCAULT, 1985, p. 207).
\end{abstract}

Foucault estabelece, como primeiro aspecto importante da passagem, que o discurso sobre Eros na arte da corte gira em torno do amado, principalmente de suas qualidades físicas individuais, da beleza de seu corpo e da delicadeza de seus gestos. Sendo assim, o passo indevido dado pelos discursos de todos os participantes do simpósio que antecederam a intervenção da sacerdotisa foi o de atribuir a Eros aquilo que era tão somente parte das qualidades individuais do objeto amado. E o amor, o verdadeiro amor, não pode repousar, obviamente, só nas qualidades individuais do ser humano, por mais belo que seja. Há nisso também uma problemática nitidamente formativa: o Eros pedagógico que brota daí, como vimos acima, esgota-se rapidamente, porque depende de uma beleza efêmera e de uma satisfação passageira geralmente interesseira e egoísta do amante. Quando findada a beleza do amado ou saciado o desejo do amante, Eros perde o sentido de existir, apagando-se também a energia inflamada que o movia. Por ter fincado morada na transitoriedade humana e tê-la tomado como definitiva, Eros vê sua luz se esvanecer. Nesse sentido, o autoengano dos amantes, tanto do erasta como do erômeno, ao tomar o efêmero como definitivo, querendo elevar aquilo que é vulnerável à condição eterna, só pode ser superado pela mudança de perspectiva que possa reconhecer a fragilidade de Eros sem, ao mesmo tempo, aniquilar sua força transformadora. Foucault tem claro, então, que não é a arte da corte, mas sim a dialética do amor, que é capaz de realizar essa tarefa. Daí, nesse sentido, a grandeza espiritual e formativa da dialética filosófica em relação às outras expressões culturais e profissionais, como a retórica, a medicina e a poesia trágico-cômica. Ela, a dialética, põe o problema da verdade em outro nível, fazendoo brotar do jogo erótico entre perguntas e respostas, conduzido por um novo perfil de erasta (Sócrates), que, ao reconhecer sua ignorância, não se atém mais obsessivamente ao embelezamento das palavras e 
nem se deixa seduzir pela beleza física do amado, mas faz sim de seu exercício dialético a busca sincera pela verdade. É o autogoverno de Sócrates em relação às possíveis seduções, provocadas pela beleza individual, que o transforma em força erótica para seu erômeno, elevando-o da esfera da doxa à busca do saber, ou do âmbito do amor fugidio à busca do verdadeiro. Portanto, seu autodomínio o transforma em um mestre que, por ter alcançado condição virtuosa mais elevada (de excelência), assume o papel de condutor espiritual da alma de seus discípulos, direcionando-o, por meio de questionamentos constantes, para a busca do amor pela sabedoria.

É preciso considerar que a interpretação que Foucault faz da dialética do amor no Banquete insere-se no seu projeto filosófico maior de elaborar uma nova genealogia do sujeito, a qual começa a se intensificar a partir do final dos anos de 1970 e transforma-se no núcleo de sua produção intelectual dos últimos quatro anos de sua existência. Contrapondo-se a duas perspectivas dominantes de interpretação do sujeito, a analítica e a marxista, Foucault procura recolocar o sujeito no domínio histórico das práticas e processos por meio dos quais ele se transforma continuamente. Nesse sentido, os volumes II e III da História da sexualidade investigam, cada um à sua maneira, as diferentes práticas de si, ou seja, as diferentes tecnologias de si, ocorridas na Antiguidade greco-latina, que visam à formação ética do sujeito. Também é nesse sentido que o material reunido nesses dois volumes, publicado somente após a morte de Foucault, preparam as bases intelectuais das investigações dos anos de 1980, incluindo entre elas, principalmente, o curso de 1982, editado posteriormente sob o título de $A$ bermenêtica do sujeito. $\mathrm{O}$ fato é que a nova genealogia do sujeito, calcada na investigação das práticas de si antigas, abre a possibilidade de colocar o sujeito na condição ativa, concedendo-lhe certa autonomia relativa. Tem-se com isso, então, o pano filosófico de fundo que permite compreender a relação entre erasta e erômeno como relação complementar e tensionada nos termos de uma dialética do amor na qual tanto amante como amado buscam a autonomia, embora nunca garantida ou alcançada de maneira definitiva, porque tal autonomia "é a dobra dos processos de subjetivação sobre os procedimentos de sujeição, segundo duplicações, ao sabor da história, que mais ou menos se recobrem" (GROS, 2004, p. 637).

Um segundo aspecto do que foi dito ressalta a importância da guinada ontológica como sustentação filosófica da dialética do amor. Foucault esclarece que a verdade de Eros depende da investigação do que ele é em si mesmo; isso exige o deslocamento ontológico, com claros desdobramentos pedagógico-formativos, do "quem ele ama" (ton eromenon) para "aquele que ama" (to eron). Eros readquire seu brilho, conseguindo iluminar o que está à sua volta não só quando abandona o foco restritivo da figura do amado, mas também quando se desenlaça dos desejos imediatos, meramente egoístas, do amante. No contexto da guinada ontológica, a relação entre os amantes assume outro nível, passando a ser conduzida diretamente pela sabedoria experiencial do erasta. Em síntese, o deslocamento aludido acima atribui ao erasta papel indispensável na busca do verdadeiro amor. Contudo, o desempenho de tal papel depende da presença do erômeno e de certa maneira específica, não só ontológica, mas também formativa, de tratá-lo. Diante disso, torna-se oportuno perguntar: de que capacidades deve dispor o erasta para assumir tão elevado papel? Consegue ele efetivamente cumprir essa grandiosa tarefa? E, ainda, em que condições ele pode suportar a busca pelo Eros verdadeiro, levando a sério o erômeno? Essas questões, ao perfilarem a condição ontológica do erasta, definem, ao mesmo tempo, a força formativa de Eros, arrancando o erômeno de sua condição passiva e colocandoo na posição de sujeito ativo, que passa a se incomodar com sua anterior condição, a de se deixar mover tão somente por sua beleza corpórea individual. Desse modo, o erômeno, ao ser tocado (fisgado) pela força erótica do erasta, passa a perceber a beleza de outros corpos, a beleza da vida política na polis, do conhecimento e da contemplação da beleza em si.

Por isso, a guinada ontológica põe os amantes a caminho do verdadeiro amor. Não podemos mais pensar, como usualmente ainda se pensa, que o amor platônico está isento de limitações e que, por pressupor uma condição humana perfeita, seria inalcançável pelo próprio ser humano. Um dos méritos da interpretação de Foucault consiste precisamente em insistir que a guinada ontológica, em vez de afastar o Eros da condição humana, colocando-o em um patamar inalcançável, faz exatamente o contrário, atingindo-a em cheio, ao revelar sua trágica ambiguidade. O discurso da sacerdotisa, deixandose orientar nitidamente pelo caminho ontológico das palavras, atribui rigor dialético à teogonia (Fedro), à medicina (Erixímaco), à comédia (Aristófanes) e à tragédia (Agatão), reelaborando filosoficamente o mito originário do qual provém Eros. Ora, é a reinterpretação filosófica do mito que permite emergir, 
com intensidade antes não percebida, a fragilidade da condição humana. Como a sacerdotisa nos faz lembrar, durante os festejos de comemoração do nascimento de Afrodite, deusa da beleza, Poros (Recurso) fecunda Penia (Pobreza), que dará à luz Eros, marcando com isso sua condição ambivalente: ele é filho tanto da bonança como da pobreza, do cheio como do vazio, do excesso como da falta.

Nesse contexto, Donaldo Schüler resume bem o significado da dupla filiação de Eros: "Degradado a filho de Recurso e de Pobreza, Eros sai do mundo de Zeus e cai no domínio do homem. Sobrevive ferido, contaminado de morte, limitado e lento. Este já não é o Eros que fere. Convém-lhe melhor a imagem do ser ferido, anelante, sequioso de socorro para o incurável" (SCHÜLER, 2001, p. $82)$.

Uma vez caído no domínio humano, Eros caracteriza-se pela fragilidade e falta, sendo justamente dessa sua carência que nasce a necessidade da cultura e, especialmente, da educação. Se fosse completo, não precisaria mais buscar o saber, pois já estaria de posse da verdade; se estivesse plenamente satisfeito, não teria mais desejo e, com isso, a presença do outro lhe seria indiferente. Amante e amado se enlaçam em uma luta amorosa porque lhes falta algo a ambos, e Eros, força meia humana e meia divina, regula tal luta para que os amantes possam se libertar de seus desejos imediatos e, de forma complementar, ponham-se a caminho, na busca do verdadeiro amor.

A filiação materna de Eros, quando devidamente reconhecida por ele mesmo, impede-o de querer assumir soberbamente a condição onipotente. Por isso, a presença de sua mãe lembra-o constantemente de sua origem humilde e, em respeito a tal origem, a necessidade de buscar agir como convém, sem pretender ser, arrogantemente, o que não é. Sua filiação paterna, por sua vez, conduz Eros a não ficar entrincheirado em sua própria limitação, e aceitar passivamente o destino de sua vulnerabilidade. De outra parte, Recurso abre-lhe o mundo das capacidades, possibilitando-lhe chamar o outro para vir em seu socorro, para superar suas próprias limitações. A dialética do amor consiste, então, em querer superar as limitações da pobreza sem cair nas tentações da soberba. E tal superação implica luta, ascese e trabalho incessante de si sobre si mesmo. Não se trata, por isso, de atribuir dominância nem só a Recurso e nem só à Pobreza, uma vez que um, isoladamente, não pode existir sem o outro: se Eros é gestado e parido por Penia, só pode sê-lo porque fora fecundado por Poros. Por isso, é a tensão permanente entre o excesso e a falta que torna Eros uma figura mediadora; como tal, precisa interpretar o sentido da dupla linguagem da qual ele próprio é constituído, a humana e a divina, tendo de colocá-las em permanente diálogo. Essa dupla origem faz de Eros o que ele é; se fosse movido só pela abundância, não teria desejo; constituído só pela falta, não teria força suficiente para satisfazer seu próprio desejo. Se o desejo brota da falta, a possibilidade de satisfazê-lo de maneira ordenada depende da condição humana temperante, ou seja, do autogoverno de si mesmo. É justamente com o problema do domínio de si mesmo, ou seja, do autogoverno dos amantes que, como veremos em seguida, o papel formativo de Eros ganha força e intensidade.

Em síntese, quando Eros é investigado em sua origem, em sua própria natureza, como ele é em si mesmo, ele surge, então, da dialética entre duas forças, Recurso e Pobreza, tendo de percorrer sempre uma linha tênue, "quebradiça", pois a predominância excessiva de uma força conduziria imediatamente à morte da outra e, finalmente, à morte do próprio Eros. Desse modo, o Banquete mostra, em sua interpretação dialética do mito de origem, a tensão constitutiva de Eros: é um ser frágil que possui capacidades de se elevar acima de sua própria fragilidade, mas não de maneira definitiva e nem absoluta, uma vez que sua carência é "incurável". Em todo o caso, a guinada ontológica abre um campo fértil para o processo formativo humano, pois, ao elevar a relação entre os amantes para o nível de uma complementaridade incontornável, prepara-os para a busca da verdade. $\mathrm{Na}$ sequência, vamos analisar, seguindo ainda Foucault, em que sentido o jogo amoroso orientado pela busca da verdade exige a transformação profundamente ética de ambos, tanto do erasta como do erômeno.

A guinada ontológica provoca, como vimos, o deslocamento das qualidades do amado para as virtudes do amante, do discípulo para o mestre; ou seja, passa-se do amor fugidio, próprio à arte da corte centrada na honra do rapaz, para o amor verdadeiro, próprio à dialética do amor. Essa guinada pode levar a dois mal-entendidos que precisam ser aqui evitados: primeiro, à posição de soberania absoluta do erasta (mestre) e, segundo, à consequente desvalorização corporal do erômeno (discípulo). No que se refere à supremacia inquestionável do mestre, a dialética do amor não pode pô-lo em uma posição absoluta, inalcançável pelo discípulo, pois a busca pela verdade é um caminho percorrido sempre 
a dois, nunca isoladamente, pois a presença do discípulo auxilia inclusive para suprir a carência do mestre. Sem a presença do discípulo, o mestre afundaria na mais absoluta solidão destruidora, sem poder pôr em prática sua energia erótica formativa. O mestre só se torna mestre e pode assumir essa sua condição pela consciência que possui de suas próprias limitações. É precisamente essa consciência que o conduz a ver a indispensabilidade do discípulo, de levá-lo a sério em sua significação ética, de tratá-lo como um outro que também ama e pode amar de modo verdadeiro. Ora, é a consideração do discípulo nessa perspectiva ética que ajuda a aplainar o caminho revezado e tortuoso da busca pela verdade.

No que se refere ao corpo, possível segundo mal-entendido, sua beleza física, sua harmonia e delicadeza nos gestos, constitú, como vimos, o centro da arte da corte. Agora, na dialética do amor, a beleza individual é secundarizada sem que o próprio corpo seja desvalorizado. Ao contrário disso, ele é elevado à condição de fundamento da espiritualidade, assumindo, portanto, papel importante para balizar eticamente a relação entre os amantes: a beleza física é conduzida a ver-se diante do esplendor da beleza universal e, com isso, a ter de se confrontar com o belo em si, redimensionando suas carências e desejos. Foucault reconstrói com clareza o percurso desencadeado por Platão: "De um belo corpo, para os belos corpos, conforme a bela fórmula do Banquete, em seguida destes para as almas, depois para o que existe de belo nas 'ocupações', 'as regras de conduta', 'os conhecimentos', até que, finalmente, o olhar atinja 'a vasta região já ocupada pelo belo’, o movimento é contínuo”. (FOUCAULT, 1985, p. 209).

Desse modo, a beleza do corpo, conduzida pelo Eros formativo, estende-se em um movimento contínuo até a vasta região do belo em si, passando pelo que há de comum na beleza entre os seres humanos. ${ }^{6} \mathrm{O}$ fato é que, na busca pelo amor verdadeiro, novas exigências são postas tanto ao erasta como ao erômeno, mas nenhuma delas redunda na depreciação do corpo. Em clara alusão corretiva ao grande equívoco de interpretação cometido contra Platão, Foucault conclui lapidarmente: "Não é a exclusão do corpo que caracteriza essencialmente, para Platão, o verdadeiro amor; é que ele [o corpo] é, através das aparências do objeto, relação com a verdade" (FOUCAULT, 1985, p. 209). Portanto, quando o corpo é confrontado com o belo em si, adquire energia para, por meio das aparências do objeto, poder relacionar-se com a verdade. O corpo não pode jamais negar sua condição de estar em fina sintonia com "as aparências do objeto" e de, às vezes, até mesmo confundir-se com elas. Cabe ao logos, contudo, investigar em que sentido "as aparências do objeto" podem conduzir ao engano.

A dialética do amor consiste, então, precisamente nisso, não em negar tais aparências, mas sim, em um movimento erótico formativo continuo, em buscar pô-las, de degrau a degrau, em contato com outra dimensão da vida humana, ou seja, com aquela que é capaz de ir além da beleza individual e ver as coisas sob o ponto vista geral, mais abrangente e, certamente, menos viciado. O grande limite de erasta e erômeno no âmbito da arte da corte repousa justamente no fato de terem sucumbido, cada um ao seu modo, à beleza individual e de quererem saciar obsessivamente seus desejos imediatos. Agora, confrontados com o Eros dialético, sentem-se obrigados a ampliar o ponto de vista da beleza individual e reordenar seus próprios desejos à luz da beleza universal. Em síntese, de agora em diante, no âmbito da dialética do amor, o que predomina e orienta a relação entre os amantes é o desejo ardente da sabedoria, a qual é condição indispensável da busca pelo amor verdadeiro.

Ocupamo-nos até aqui com a primeira questão posta no primeiro parágrafo deste tópico, ou seja, com o conteúdo da guinada ontológica que está na base da nova significação que Eros adquire no âmbito da dialética do amor. Precisamos debruçar-nos agora sobre a segunda questão, delineando os traços do novo perfil que erasta e erômeno adquirem na busca pelo verdadeiro amor, investigando também a nova forma que a relação entre eles assume em comparação com a arte da corte. Ambos, tanto amante como amado, precisam passar por profunda transformação para que possam resistir às seduções da beleza individual e à satisfação dos desejos ardentes e imediatos que dela resultam. Essa batalha heroica consigo mesmo torna nobre a alma dos amantes, elevando-os ao verdadeiro amor. Antes de seguir com o Banquete, referimos uma passagem do Fedro, na qual Platão resume um aspecto importante da dialética do amor que toma conta da relação entre os amantes. Assim afirma o filósofo do amor:

Ora, quando vence a melhor parte da alma que conduz à vida bem-ordenada e ao amor à sabedoria, então eles [amante e amado] seguem já aqui mesmo uma vida feliz e de acordo consigo mesma, por saberem dominar-se a si mesmos e possuírem uma conduta virtuosa,

\footnotetext{
${ }^{6}$ Para uma interpretação consistente do diálogo platônico na perspectiva da scala amoris, ver o estudo de Kurt Sier (1997).
} 
triunfando sobre a parte má da alma e libertando sua parte excelente que conduz à virtude (FEDRO, 256a). ${ }^{7}$

Nesse sentido, o Fedro descreve o modo como a relação amante e amado se enlaça em uma luta constante entre vício e virtude, sendo que é a vitória da melhor parte da alma que assegura a experiência do verdadeiro amor. Isso significa dizer, em outras palavras, que a virtude é a excelência na execução da ação e justamente por isso empurra os amantes na direção da busca pela verdade. De outra parte, torna-se claro, com isso, que o discurso de Sócrates no Fedro mostra o domínio virtuoso de si mesmo como resultado de uma batalha incessante entre os amantes, um com o outro e de cada um consigo mesmo. Foucault resume a contribuição desse diálogo para a teoria do amor nos seguintes termos: "Sócrates descreveu o caminho, o ardor, os sofrimentos daquele que ama e o duro combate que teve que travar para dominar sua equipagem" (FOUCAULT, 1985, p. 210). Ao serem inflamados pela energia de Eros e desejando viver o verdadeiro amor, amante e amado precisaram dispor-se a encetar o difícil caminho ético do domínio de si e resistir à força destruidora de seus desejos imediatos, efêmeros e passageiros. Desse modo, no âmbito da dialética do amor, diferentemente da arte da corte, são os dois, amante e amado, impelidos ao amor verdadeiro e, por isso, ambos, e não somente um deles, precisam mudar sua forma de vida. Foucault conclui: "Diferentemente do que se passa na 'arte de cortejar', a 'dialética do amor' exige aqui nos dois amantes, dois movimentos exatamente semelhantes; o amor é o mesmo, posto que é, tanto para um como para outro, o movimento que os arrebata para o verdadeiro." (FOUCAULT, 1985, p. 210).

Contudo, essa exigência feita aos dois amantes impõe singularidades a cada um deles: Sócrates, justamente por conta de sua enkrateia, continua atento aos seus apetites e desejos; Alcibíades precisa sair da mera condição de objeto passivo, engalfinhado soberbamente em sua própria beleza, e colocar-se ativamente ao lado de Sócrates, na procura do amor. Um precisa do outro, pois isoladamente nenhum consegue encetar o caminho do Eros verdadeiro. Na sequência, vamos nos ocupar primeiro do perfil de Sócrates, paradigma do Eros formativo e, depois, de Alcibíades, figura exemplar do erômeno que, ao estranhar-se com a sabedoria formativa do mestre, tem diante de si a possibilidade de se transformar ele mesmo em novo erasta. Na interpretação de Foucault, a dialética do amor do Banquete exige de Sócrates um perfil eminentemente ético, fazendo com que Alcibíades passe a admirá-lo exatamente por causa dessas suas qualidades morais. Paradoxalmente, Sócrates, "o homem velho, de corpo sem graça", passa a assumir o papel de erômeno, ou seja, torna-se objeto de amor de Alcibíades, o qual, em posição invertida, assume o papel de erasta. Mas, como é possível tal inversão? Para tornarse mestre da busca pelo amor verdadeiro, Sócrates precisou resistir às seduções provocadas pela beleza dos rapazes, atingindo um nível tão elevado de domínio de si que despertou o enamoramento de Alcibíades, o qual, por sua vez, sentiu-se inflamado pela profunda capacidade espiritual do mestre de se conter a si mesmo e, fazendo parar de pulsar seus próprios desejos imediatos, tem a oportunidade de dirigir seu olhar para o belo em si. Por ter alcançado o discernimento de "amar o verdadeiro que convém amar", Sócrates, com sua feiura corporal, despertou, mesmo assim, e talvez precisamente por isso, o amor intenso do belo rapaz. Por exercer o autodomínio de si, toma posse da maior sabedoria possível, transformando-a em Eros formativo. Com isso, atrai o discípulo com o mesmo enfeitiçamento que empurra a mariposa para a luz.

Em síntese, o ponto nuclear da interpretação foucaultiana é que Sócrates, no âmbito da dialética do amor, consegue tornar-se um mestre da verdade, ou seja, da busca incessante pela verdade, porque assume forma ascética de vida. São, então, exercícios constantes, incluindo as provações físicas, como, por exemplo, o andar descalço na geada, como também os exercícios espirituais frequentes que exigem dele a capacidade de se isentar de seu próprio corpo e de se concentrar na meditação profunda consigo mesmo. Tudo isso o torna um ser temperante, que não se deixa guiar nem pelo excesso e nem pela falta. Ora, é tal temperança, conquistada a duras penas e sempre tendo que ser provada diariamente, que o torna um mestre do Eros formativo a caminho da verdade. Porque soube tornar-se senhor de si mesmo, esforçando-se para encontrar a medida das coisas e deixando livre tudo aquilo que produz a virtude, é que Sócrates atraiu Alcibíades para o caminho do amor verdadeiro. Enfeitiçado pelo Eros formativo do mestre, Alcibíades tem a possibilidade de saber mais sobre a beleza universal e sobre o

\footnotetext{
${ }^{7}$ A tradução para o português da edição alemã empregada, publicada pela Insel Verlag, é de nossa autoria.
} 
quanto ela, em sua relação com a bondade, permite o acesso à verdade. Contudo, para poder fazê-lo, Alcibíades precisa superar os limites de seu ponto de vista restrito à beleza individual.

Voltemo-nos agora mais pontualmente para Alcibíades, buscando investigar, ainda na companhia de Foucault, em que sentido ele toma parte do Eros formativo, na condição ambígua de ser um erômeno que, ao levar Sócrates a sério, transforma-se em novo erasta. Nessa condição ambígua, polivalente, Alcibíades não pode mais, por um lado, colocar-se na posição passiva, de ser apenas objeto do desejo de seu mestre. O próprio Sócrates, como acabamos de ver, movido pela dialética do amor, não aceitaria tomar Alcibíades como erômeno a satisfazer seus desejos imediatos. Sócrates, tocado pela chama do Eros verdadeiro e travando intensa batalha consigo mesmo, esforça-se para superar seus desejos imediatos e, por isso, fascina Alcibíades com o poder demoníaco de sua força virtuosa e o leva a fazer o mesmo. Por outro lado, quando Alcibíades reconhece em Sócrates o poder do Eros formativo, precisa fazê-lo na condição de um erômeno independente, isto é, sem aniquilar seu si mesmo diante da força erótica do mestre. Ora, essa ambivalência inerente à postura de Alcibíades precisa ser compreendida mais de perto, pois ela constitui, do lado do erômeno, a própria dialética do amor: buscar sua condição de sujeito ativo inflamado pela chama do Eros formativo do mestre, mas fazê-lo de tal forma que não comprometa a possibilidade de se tornar, ele mesmo, futuro erasta.

Platão reserva a Alcibíades, no Banquete, o último discurso elogioso ao amor. Alcibíades, por sua vez, não faz o elogio ao amor, mas sim ao Eros formativo de Sócrates. Trata-se, talvez, na história da relação formativa entre erasta e erômeno, entre mestre e discípulo, de um dos elogios mais apaixonados, de um dos mais belos reconhecimentos que um discípulo pode tributar ao seu mestre. Alcibíades, como sabemos pela narrativa platônica, dá entrada na casa de Agatão, local onde ocorria o simpósio, bêbado e de maneira estridente, falando alto e arrastando atrás de si um grupo de desocupados, tão bêbados quanto ele. Quer visitar Agatão, o belo e jovem rapaz, mas se depara com Sócrates, cuja presença o desconcerta. Ao avistar Sócrates, Alcibíades eleva-se para um outro tipo de embriaguez, muda de perspectiva e começa a enxergar o que antes o cegava. Em vez de fazer um discurso de elogio ao amor, como todos os outros oradores que o antecederam, prefere destacar publicamente as virtudes de Sócrates.

O discurso elogioso de Alcibíades a Sócrates é longo e abrange várias facetas do Eros formativo do mestre. Ele diz, por exemplo, que Sócrates é o único que o faz voltar-se sobre si mesmo e perceber suas próprias deficiências; que o provoca ao autoexame permanente, conduzindo-o a sentir-se envergonhado daquilo que faz ou deixa de fazer; que é o único que consegue arrancá-lo do mundo político e de sua paixão doentia pela popularidade. Tudo isso Alcibíades reconhece em Sócrates, com sinceridade, mesmo que esse seu reconhecimento deponha contra suas próprias atitudes e o desmascare frente aos seus próprios convivas. Mas propriamente elucidativas são as duas metáforas que ele emprega para expor as virtudes do Eros formativo de seu mestre: primeiro, compara Sócrates com uma estátua de sileno e, em seguida, com o homem picado por uma cobra venenosa. Essas duas metáforas dizem muito do efeito tenaz, inflamado, que o trabalho formativo do mestre provoca no discípulo. As pequenas esculturas de Sileno colocadas nas oficinas dos estatuários eram muito feias por fora, mas, ao serem abertas, guardavam em seu interior estatuetas de deuses, ou seja, uma riqueza interior impagável. Assim era Sócrates, feio na aparência física, mas rico no cultivo do espírito; horroroso por fora, mas belo por dentro. No que se refere à metáfora da cobra, Alcibíades compara o efeito que as palavras de Sócrates exercem sobre sua alma com a reação que um homem sente ao ser picado por uma cobra venenosa: tal homem nega-se a falar com qualquer um sobre o acontecido, relatando somente para quem sofreu coisa semelhante, pois é tal pessoa que está em condições de compreender as loucuras que ele cometeu sob o efeito da dor terrível que sentia. Se o veneno provoca retorces horripilantes, deixando fora de si quem sofreu a picada, os discursos filosóficos movidos pelo Eros formativo são de ação ainda mais profunda do que a do veneno das víboras, quando atuam na alma jovem e bem-nascida e a levam a tudo dizer e realizar (PLATÃO, 1991a, 218a).

$\mathrm{Na}$ descrição metafórica de Alcibíades, Sócrates guarda a riqueza interior de um Sileno e provoca um retorce mais violento, a quem se dispõe a ouvi-lo, do que o veneno da víbora mais tenebrosa. Contudo, o que o alto elogio a Sócrates mostra do perfil do próprio Alcibíades? Em que sentido tornao um erômeno independente, transformando-o simultaneamente em novo erasta? O reconhecimento da força embriagante do Eros formativo do mestre, se levado realmente às últimas consequências, 
provocaria uma profunda transformação no discípulo, obrigando Alcibíades a abrir mão de sua vaidade, autossuficiência e de sua profunda enamoração narcísica. No dizer de Donaldo Schüler (2001, p. 94): "Alcibíades confessa o inconfessável, expõe a ferida interior, a sua fraqueza, que não consta e não pode constar nas páginas da história, fraqueza que relatada por outro não mereceria confiança”.

Mas, esse reconhecimento a Sócrates não o endeusaria excessivamente? Como o mestre do Eros formativo se protege do risco de seu próprio narcisismo? Foucault vem aqui, novamente, ao nosso socorro: "Sócrates introduz um outro tipo de dominação: a que é exercida pelo mestre de verdade e para a qual ele é qualificado pela soberania que exerce sobre si mesmo" (FOUCAULT, 1985, p. 212). Ou seja, é precisamente essa sua grande virtude, referida ao domínio de si, que transforma Sócrates repentina e paradoxalmente no novo erômeno, cuja sabedoria experiencial é ardentemente amada por Alcibíades, o novo erasta. De erômeno Alcibíades vê-se, então, transportado, pela força da dialética do amor, à condição de erasta, de um amante que não cobiça mais só a beleza individual do amado, até porque Sócrates dispõe não da beleza corpórea, mas sim de uma sabedoria que brota de sua busca incansável pelo autogoverno de si.

\section{CONSIDERAÇÕES CONCLUSIVAS}

No Banquete, Platão desenvolve nova teoria do amor em contraposição às teorias elogiosas existentes na época. Com fineza filosófico-literária inigualável, soube reter criticamente o que havia de aceitável no elogio do amor de procedência retórica, médica, política e no âmbito da poesia cômicotrágica. Sua dialética do amor possibilitou a passagem da perspectiva individualista, restrita à satisfação dos desejos radicados na beleza corpórea individual, para o ponto de vista mais abrangente, construído pela tensão entre os ideais normativos da beleza, bondade e verdade. No bojo dessa guinada ontológica das seduções impostas pela beleza corpórea individual para a pergunta sobre o que é o belo em si, colocase uma ideia profunda de formação humana, que sempre exige relação complementar entre os amantes, parceiros na busca cooperativa pela verdade, fazendo com que, na experiência inflamada do jogo amoroso, um se esforce para compreender o ponto de vista do outro.

Resta-nos ainda, contudo, uma dúvida, depois desse percurso feito, no qual nos deixamos guiar de perto pela interpretação de Foucault: teria Alcibíades de fato se transformado radicalmente a ponto de assumir com sinceridade a força da dialética do amor? E, em relação a Sócrates, teria ele efetivamente se tornado o mestre formativo à procura da verdade, a ponto de aceitar Alcibíades como ele é e, a partir de tal aceite, iniciar efetivamente o processo formativo de seu discípulo? Em síntese, para haver efetivamente uma dialética formativa do amor, cada um não precisaria ter se deslocado da exclusividade de seu ponto de vista? Alcibíades, do sono dogmático restrito à beleza corpórea individual e, Sócrates, de sua contemplação obcecada do belo em si? Esse questionamento nos conduz a reler, novamente, não só a interpretação, até certo ponto generosa a Platão, que Foucault faz do Banquete, mas também o próprio diálogo platônico. Levar adiante esses questionamentos implicaria imaginar, entre outras coisas, qual teria sido propriamente a resposta de Sócrates, ao final do Banquete, se ele tivesse continuado a dialogar diretamente com Alcibíades. Contudo, de uma coisa temos certeza - e isso abre a possibilidade para uma interpretação historicizada do Banquete e, com ela, uma ideia de formação humana que procuramos defender aqui -, o ingresso estridente e destrambelhado de Alcibíades no simpósio promovido por Agatão e narrado por Platão serviu, ao menos, para arrancar Sócrates do mundo inteligível e trazê-lo de volta para o mundo sensível (GOLDSCHMIDT, 2002, p. 220).

De qualquer sorte, Platão esboça, embrionariamente, as bases de uma teoria educacional crítica, cuja força precisa ser mantida e atualizada sob vários aspectos. O primeiro deles caracteriza a busca incansável do autogoverno humano como condição da participação livre na esfera pública. Platão nos ensina magistralmente que esse nexo estreito entre governo de si e governo dos outros só é possível mediante a superação do ponto de vista individualista (narcisista) e a inclusão do outro com base em uma perspectiva mais ampla, oriunda da pergunta pelo belo em si. Nos dias atuais, marcados pela radicalização de projetos individualistas e pelo acentuado esforço de privatização e sucateamento de todas as dimensões da esfera pública democrática, precisamos mais do que nunca ampliar nosso espírito e procurar ver as outras pessoas, a sociedade e o mundo a partir de perspectivas plurais, mais abrangentes, pois o fortalecimento da democracia depende do espírito alargado, que se forma pelo processo de estranhamento que nos faz sair de nosso mundo restrito e nos colocarmos no lugar do outro. Não 
precisamos hoje, ainda mais, daquele estranhamento causado pelo Eros formativo, que nos faz nos retorcermos e revirarmos com mais intensidade do que o efeito letal de uma víbora venenosa?

Em segundo lugar, a força do Eros formativo, quando alcança o âmbito da dialética do amor, ainda permanece atual em sua exigência de permanente autoexame crítico. A força formativa de Eros repousa na disposição humana de abertura para sentar-se lado a lado e, na forma de um simpósio, primeiro, ouvir atentamente o que o outro tem a dizer e, somente depois de tê-lo seguido nas minúcias de sua fala, formular o juízo crítico, aceitando do parceiro o que precisa ser mantido e distanciando-se dele naquilo que se torna inaceitável. O simpósio grego antigo, como possibilidade do diálogo humano, reatualizou-se historicamente, assumindo novas e diferentes formas de expressão cultural, envolvendo um círculo muito mais amplo de seres humanos, como crianças, negros e mulheres, antes excluídos da roda do banquete. Precisamente por isso, permanece como grande desafio reatualizar o inusitado formativo $^{8}$ possibilitado pelo simpósio antigo, enquanto espaço do diálogo humano. Desse modo, Agatão, ao organizar a festa, não poderia prever antecipadamente que Sócrates fosse expor sua dialética do amor por meio da intervenção discursiva da sacerdotisa Diotima. Tampouco poderia o jovem belo e vitorioso poeta imaginar previamente a irrupção estrondosa do bêbado Alcibíades e, menos ainda, seu relato enamorado sobre Sócrates e sua revelação das transformações sofridas ao escutá-lo atentamente, em muitas outras oportunidades anteriores. Podemos nos perguntar, em dias atuais, de brutal barbarização crescente da vida humana e social, quanto mais ainda não precisamos da dialética do amor revelada pela sacerdotisa ou de relatos sobre profundas transformações formativas, como o de Alcibíades?

Por fim, a grande atualidade da dialética do amor platônico repousa, inequivocamente, na compreensão adequada do caráter complementar incontornável da relação ética entre educador e educando, provocando a transformação de ambos em sujeitos ativos da relação ensinante e aprendente: o educador só consegue cumprir seu papel de ensino quando se dispõe a assumir a condição humilde de se colocar ele mesmo na posição de educando, ou, ao menos, de esforçar-se para ver o processo formativo pela ótica de quem precisa apropriar-se de algo que lhe falta e que, por isso, lhe é completamente estranho. Sem que o educador faça ele mesmo o processo de estranhamento, descobrindo a própria falta que o constitui, não consegue levar o estranho ao seu educando. De outra parte, o próprio educando só consegue cumprir seu papel de aprendente se almejar a condição de ensinante, pois é ela que se transforma em força erótica, criando as condições para que ele, o educando, possa apropriar-se do que lhe é estranho. No mundo atual, marcado pelas comodidades da tecnologia digital e pelas facilitações proporcionadas pelas metodologias ativas, não precisamos, ainda mais, da dialética do amor que possibilite a compreensão da complementaridade ético-formativa que constitui a relação genuína entre os amantes do saber? Mas por que a formação humana precisa insistir em tal compreensão? Porque ela está na origem do autogoverno moral de si mesmo, que é condição indispensável para a deliberação livre e democrática na esfera pública.

\section{REFERÊNCIAS}

DALBOSCO, Claudio Almir; SANTOS, Francisco; MARASCHIN, Renata; CEZAR, Luciana, Oltramari. Medical discernment and dialogical praxis: treatment as healing oneself. Medicine Health Care and Philosophy, v. 23, p. 205-214, 2020.

FERRARI, Giovanni Rf. Amor platônico. In: KRAUT, R. (Org.). PLATÃo. São Paulo: Editora Ideias \& Letras, 2013. p. 293-325.

FOUCAULT, Michel. História da sexualidade, 2: O uso dos prazeres. Rio de Janeiro: Edições Graal, 1985.

\footnotetext{
${ }^{8}$ Esse aspecto do inesperado que aparece no simpósio grego como expressão cultural e, especificamente no Banquete de Platão, é característico da ação humana e do ato educacional. Para uma investigação sobre a importância dos acontecimentos incontrolados para se compreender a condição humana, ver o estudo O conbecimento do amor, de Martha Nussbaum (2005).
} 
GOLDSCHMIDT, Victor. Os diálogos de PLATÃO: estrutura e método dialético. São Paulo: Edições Loyola, 2002.

GROS, Frédéric. Situação do curso. In: FOUCAULT, M. A hermenêutica do sujeito. São Paulo: Martins Fontes, 2004. p. 613-661.

HADOT, Pierre. Ejercicios espirituales y filosofia antiga. Madrid: Edições Siruela, 2006.

JAEGER, Werner. Paideia: die Formung des griechischen Menschen. Berlin/New York: Walter de Gruyter, 1973.

JAEGER, Werner. Paideia: a formação do homem grego. São Paulo: Ed. Martins Fontes, 1995.

NUSSBAUM, Martha. El conocimiento del amor: ensayos sobre filosofia y literatura. Madrid: Minimo Transito, 2005.

PLATÃO. Sämtliche werke IV: Symphosium und Phaidon. Griechisch/Deutsch. Frankfurt am Main: Insel Verlag, 1991a.

PLATÃO. Sämtliche werke VI: Phaidros und Theaitetos, Band VI. Griechisch/Deutsch. Frankfurt am Main: Insel Verlag, 1991b.

SCHÜLER, Donald. Dialética e retórica. São Paulo: Edusp, 2001.

SIER, Kurt. Die Rede der Diotima. Untersuchungen zum Platãoischen ‘Symposium’. Stuttgart/Leipzig: Franz Steiner Verlag, 1997.

WOLF, Francisco. Eros e Logos: a propósito de Foucault e PLATÃO. In: Discurso, v. 19, p. 135-164, 1992. 